\title{
Detection and Molecular Characterization of Extended-spectrum $\beta$-lactamase Producing E. coli and Klebsiella spp. Isolates of Cattle Origin in Eastern Plain Zone of Uttar Pradesh
}

\author{
V. Yadav ${ }^{1}$, R.K. Joshi ${ }^{1}$, N. Joshi², Amit Kumar ${ }^{3}$, S.V. Singh ${ }^{4}$, D. Niyogi ${ }^{5}$
}

10.18805/IJAR.B-4762

\begin{abstract}
Background: Antibiotics are widely used in animals and human for treatment without referring an antibiogram that resulted into the proliferation of ESBL producing strains. Nowadays resistance to $\beta$-lactam groups of antibiotic is expanding rapidly worldwide and threatening the public healthcare due to limited treatment options. Therefore this study aimed to detect ESBL resistance genes in $E$. coli and Klebsiella spp. isolated from various sources of cattle in this area of study.

Methods: Total 240 samples were collected during August, 2019 to June, 2020, from two districts of Eastern plain zone of Uttar Pradesh. E. coli and Klebsiella spp. isolates were confirmed using uidA and $16 S$ rRNA gene respectively. In vitro antibiotic sensitivity test was performed using disc diffusion method. ESBL producing isolates was confirmed by DDST, ESBL E-strip and PCR analysis by targeting (bla- ${ }_{\text {CTX-M-1 }}$, bla- ${ }_{\text {CTX-M-9 }}$, bla- ${ }_{\text {TEM }}$ and bla- ${ }_{\text {SHV }}$ ) genes.

Result: PCR analysis of these isolates confirmed $135(56.25 \%)$ as E. coli and 16(6.67\%) as Klebsiella spp. Antibiotics found to be most resistant were ampicillin $(89.40 \%)$ followed by cefotaxime $(72.18 \%)$, cefpodoxime $(71.52 \%)$, ceftriaxone $(66.9 \%)$, aztreonam $(61.0 \%)$ and ceftazidime $(54.30 \%)$. Total $101(66.88 \%)$ isolates were confirmed as ESBL producers using DDST and $92(60.92 \%)$ by ESBL E-strip test. ESBL genes were detected in $87(57.61 \%)$ isolates by PCR analysis and among them, bla- ${ }_{\text {CTX-M-1 }}$ was found most dominant gene.

Key words: Antibiogram, Cattle, E. coli, ESBL, Klebsiella.
\end{abstract}

\section{INTRODUCTION}

The emergence of antimicrobial resistance (AMR), especially among Enterobacteriaceae has been increasingly problematic and posses serious threat for both human and animal health (WHO, 2013). It is directly related with the use of these drugs in animal husbandry at insufficient doses and unprofessional choice which limit the treatment options. Resistant bacteria include both pathogenic and commensal organisms, with the later serving as a potential reservoir for mobile resistance elements (Khachatryan et al., 2004). Resistance among ESBL organism is mediated by enzyme Extended-spectrum $\beta$-lactamases (ESBLs) that hydrolyses most of the $\beta$-lactam antibiotics and mediates resistance against penicillins, $3^{\text {rd }}$ and $4^{\text {th }}$ generation cephalosporins (Saravanan et al., 2018). Among Enterobacteriaceae, E. coli and Klebsiella spp. are major ESBL producers and have been identified as global threat due to their increasing prevalence in livestock in last few years (Reuland et al., 2013). ESBL has been also reported in various niches as commensal in human, animals and environment. Such ecological niches may serve as reservoir and vehicle for transmission and dissemination in production animals due to their direct contact with food chain (Madec et al., 2017). Since no in depth study has been done on distribution of ESBL among cattle in this area of study and also their possible role in development of resistance to other species or pathogens. The present study will provide database to
${ }^{1}$ Department of Veterinary Microbiology, College of Veterinary Science and Animal Husbandry, NDUAT, Kumarganj-224 229, Ayodhya, Uttar Pradesh, India.

${ }^{2}$ Department of Veterinary Public Health and Epidemiology, College of Veterinary Science and Animal Husbandry, NDUAT, Kumarganj224 229, Ayodhya, Uttar Pradesh, India.

${ }^{3}$ Department of Immunology and Defense Mechanism, College of Biotechnology, Sardar Vallabhbhai Patel University of Agriculture and Technology, Meerut-250 110, Uttar Pradesh, India.

${ }^{4}$ Department of Veterinary Medicine, College of Veterinary Science and Animal Husbandry, NDUAT, Kumarganj-224 229, Ayodhya, Uttar Pradesh, India.

${ }^{5}$ Department of Veterinary Pathology, College of Veterinary Science and Animal Husbandry, NDUAT, Kumarganj-224 229, Ayodhya, Uttar Pradesh, India.

Corresponding Author: V. Yadav, Department of Veterinary Microbiology, College of Veterinary Science and Animal Husbandry, Acharya Narendra Deva University of Agriculture and Technology, Kumarganj-224 229, Ayodhya, Uttar Pradesh, India.

Email: vibhavet2005@gmail.com

How to cite this article: Yadav, V., Joshi, R.K., Joshi, N., Kumar, A., Singh, S.V. and Niyogi, D. (2022). Detection and Molecular Characterization of Extended-Spectrum $\beta$-lactamase Producing E. coli and Klebsiella spp. Isolates of Cattle Origin in Eastern Plain Zone of Uttar Pradesh. Indian Journal of Animal Research. DOI: 10.18805/IJAR.B-4762.

Submitted: 26-08-2021 Accepted: 27-12-2021 Online: 04-03-2022 
Detection and Molecular Characterization of Extended-spectrum $\beta$-lactamase Producing E. coli and Klebsiella spp. Isolates...

help the field veterinarians, pharmaceuticals and policy makers in proper selection of antibiotics for treatment.

\section{MATERIALS AND METHODS} Study area

This study was carried out in the Department of Veterinary Microbiology, C.V. Sc. and A.H. Kumarganj, Ayodhya. The samples were collected from Ayodhya and Sultanpur district of Eastern Plain Zone of Uttar Pradesh, India. The study was conducted between August 2019 and December 2020.

\section{Sample collection}

Total 240 samples (120 milk samples and 120 faecal samples) were collected from 5 tehsils of Ayodhya and 3 tehsils of Sultanpur district. Samples were collected randomly and sampling consisted of 10 normal and 5 mastitic milk samples from each of the tehsil. Likewise, 10 normal and 5 diarrhoeic faecal samples from above mentioned regions. California Mastitis Test was used for screening of mastitic milk samples. Approximately $5 \mathrm{ml}$ of milk was collected into sterilized test tubes and faecal samples were collected by swab technique. All collected samples were immediately transported to bacteriology laboratory in an icebox.

\section{Isolation and Identification}

All samples were enriched with $2 \mathrm{ml}$ nutrient broth and incubated for $24 \mathrm{hrs}$ at $37^{\circ} \mathrm{C}$. A loopful of inoculum was directly streaked on MacConkey agar plates added with $2 \mathrm{mg} /$ $\mathrm{L}$ cefotaxime and incubated at $37^{\circ} \mathrm{C}$ for $24 \mathrm{hr}$. Plates showing pink colonies were picked up and streaked on Eosine Methylene Blue agar plates. Colonies showing greenish metallic sheen were tentatively considered as $E$. coli while dark centred light purple colonies with mucoid appearance were suspected as Klebsiella spp. A single pure colony was picked up and transferred to nutrient agar slant. Further identification of the isolates was done by various biochemical tests viz. IMViC pattern, catalase test, nitrate reduction, urease test, triple sugar iron agar and sugar fermentation reaction as per the method of Edward and Ewing (1972) and PCR analysis.

\section{Extraction of genomic DNA}

The DNA templates were prepared by using snap-chill method as described by Franco et al. (2008).

\section{Molecular identification of $E$. coli and Klebsiella spp.}

All presumptively positive $E$. coli isolates were confirmed by PCR amplification using species specific uidA and Klebsiella spp. by bacteria specific 16S rRNA gene as per method described by Anbazhagan et al. (2010) and Andersson et al. (2008) respectively (Table 1 ). PCR reaction was carried out in total $25 \mu$ volume constituted $12.5 \mu \mathrm{l}$ of $2 \mathrm{X}$ EmeraldAmp GT Master Mix, $8.5 \mu \mathrm{l}$ nuclease free water, $1 \mu \mathrm{l}$ mixture of the forward and reverse primers $(0.5 \mu \mathrm{l}$ each primer, conc. $0.5 \mu \mathrm{M}$ each primer) and $3.0 \mu \mathrm{l}$ of template DNA. Amplification was performed using thermal cycler (Bio-Rad, USA). The cycling conditions of PCR are mentioned in Table 1.

\section{Antibiotic sensitivity testing}

All the confirmed isolates (151) were subjected to in vitroantibiotic sensitivity testing against 13 antibiotics of HiMedia mentioned in Table 4. It was performed by disc diffusion method (Bauer et al., 1966) on Muller Hinton agar (MHA) (HiMedia) plates inoculated with $1.5 \times 10^{8}$ organism/ $\mathrm{ml}$ and incubated at $37^{\circ} \mathrm{C}$ for $24 \mathrm{hrs}$ and isolates were classified as susceptible and resistant based on interpretation criteria of Clinical Standard Laboratory Institute (2019). The isolates showing reduced susceptibility towards cefotaxime, cefpodoxime, ceftazidime, ceftriaxone and aztreonam were screened as ESBL producers.

Confirmation of ESBL producing E. coli and Klebsiella spp. by phenotypic methods

\section{Double disc synergy test (DDST)}

The screened isolates were further confirmed by DDST using ESBL kit 1 and Kit 3 (Hi-media) (Fig 3). The commercially available discs were placed at $25 \mathrm{~mm}$ apart on MHA plates inoculated with $1.5 \times 10^{8}$ organism $/ \mathrm{ml}$ and incubated at $37^{\circ} \mathrm{C}$ for $24 \mathrm{hrs}$. The results were interpreted as per CLSI guidelines (2019).

\section{Minimum inhibitory concentration (MIC) ESBL E-test}

This test was done by placing E-strip on MHA plates inoculated with $1.5 \times 10^{8}$ organism $/ \mathrm{ml}$ and incubated at $37^{\circ} \mathrm{C}$

Table 1: Oligonucleotide primer sequences used for amplification of uidA and $16 \mathrm{~S}$ rRNA genes and PCR cycling conditions used.

\begin{tabular}{|c|c|c|c|c|}
\hline Targeted gene & Primer sequence $\left(5^{\prime}-3^{\prime}\right)$ & $\begin{array}{l}\text { Amplicon } \\
\text { size (bp) }\end{array}$ & $\begin{array}{l}\text { PCR conditions } \\
\text { and cycles }\end{array}$ & References \\
\hline uidA & $\begin{array}{l}\text { F-5'CTGGTATCAGCGCGAAGTCT3' } \\
\text { R-5'AGCGGGTAGATATCACACTC3' }\end{array}$ & 556 & $\begin{array}{l}1 \text { cycle of } 5 \text { minutes at } 95^{\circ} \mathrm{C}, \\
35 \text { cycles of } 45 \text { seconds at } 95^{\circ} \mathrm{C} \text {, } \\
55 \text { seconds at } 56^{\circ} \mathrm{C}, 1 \text { minutes at } \\
72^{\circ} \mathrm{C}, 1 \text { cycle of } 7 \text { minutes at } 72^{\circ} \mathrm{C}\end{array}$ & $\begin{array}{l}\text { Anbazhagan et al., } \\
2010\end{array}$ \\
\hline $784 \mathrm{~F}$ & F-5'AGGATTAGATACCCTGGTA3' & 265 & 1 cycle of 5 minutes at $95^{\circ} \mathrm{C}$ & Andersson et al., \\
\hline 1061R & R-5'CRRCACGAGCTGACGAC3' & & $\begin{array}{l}35 \text { cycles of } 50 \text { seconds at } 95^{\circ} \mathrm{C} \text {, } \\
45 \text { seconds at } 54^{\circ} \mathrm{C}, 1 \text { minutes at } \\
72^{\circ} \mathrm{C}, 1 \text { cycle of } 7 \text { minutes at } 72^{\circ} \mathrm{C}\end{array}$ & 2008 \\
\hline
\end{tabular}


Detection and Molecular Characterization of Extended-spectrum $\beta$-lactamase Producing E. coli and Klebsiella spp. Isolates...

Table 2: Detail of primers and PCR conditions used detection of ESBLs genes in isolates of E. coli and Klebsiella spp.

\begin{tabular}{|c|c|c|c|c|}
\hline $\begin{array}{l}\text { Targeted } \\
\text { genes }\end{array}$ & Primer sequence (5'-3') & $\begin{array}{l}\text { Amplicon } \\
\text { size (bp) }\end{array}$ & PCR conditions and cycles & References \\
\hline bla- $_{\text {СтX-M-1 }} \mathrm{gp}$ & $\begin{array}{l}\text { F-5'TTAGGAARTGTGCCGCTGYA3' } \\
\text { R-5'C GATATCGTTGGTGGTRCCAT3' }\end{array}$ & 688 & $\begin{array}{l}1 \text { cycle of } 10 \text { minutes at } 94^{\circ} \mathrm{C}, \\
30 \text { cycles of } 40 \text { sec. at } 94^{\circ} \mathrm{C}, \\
40 \text { sec. at } 60^{\circ} \mathrm{C}, 1 \text { miutes at } 72^{\circ} \mathrm{C} \text {, } \\
1 \text { cycle of } 7 \text { minutes at } 72^{\circ} \mathrm{C}\end{array}$ & Dallenne et al., 2010 \\
\hline bla- ${ }_{\text {CTX-M-9 }} \mathrm{gp}$ & $\begin{array}{l}\text { F-5' TCAAGCCTGCCGATCTGGT3' } \\
\text { R-5' TGATTCTCGCCGCTGAAG3' }\end{array}$ & 561 & $\begin{array}{l}1 \text { cycle of } 10 \text { minutes at } 94^{\circ} \mathrm{C}, \\
30 \text { cycles of } 40 \text { sec. at } 94^{\circ} \mathrm{C}, \\
40 \text { sec. at } 60^{\circ} \mathrm{C}, 1 \text { miutes at } 72^{\circ} \mathrm{C} \text {, } \\
1 \text { cycle of } 7 \text { minutes at } 72^{\circ} \mathrm{C}\end{array}$ & Dallenne et al., 2010 \\
\hline bla- & $\begin{array}{l}\text { F-5'CATTTCCGTGTCGCCCTTATTC3' } \\
\text { R-5'CGTTCATCCATAGTTGCCTGAC3' }\end{array}$ & 800 & $\begin{array}{l}1 \text { cycle of } 10 \text { minutes at } 94^{\circ} \mathrm{C}, \\
30 \text { cycles of } 40 \text { sec. at } 94^{\circ} \mathrm{C}, \\
40 \text { sec. at } 61^{\circ} \mathrm{C}, 1 \text { miutes at } 72^{\circ} \mathrm{C} \text {, } \\
1 \text { cycle of } 7 \text { minutes at } 72^{\circ} \mathrm{C}\end{array}$ & Dallenne et al., 2010 \\
\hline bla- ${ }_{\mathrm{SHV}}$ & $\begin{array}{l}\text { F-5'AGGATTGACTGCCTTTTTG3' } \\
\text { R-5'ATTTGCTGATTTCGCTCG3' }\end{array}$ & 393 & $\begin{array}{l}1 \text { cycle of } 10 \text { minutes at } 94^{\circ} \mathrm{C}, \\
40 \text { cycles of } 40 \text { sec. at } 94^{\circ} \mathrm{C}, \\
40 \text { sec. at } 60^{\circ} \mathrm{C}, 1 \text { miutes at } 72^{\circ} \mathrm{C} \text {, } \\
1 \text { cycle of } 7 \text { minutes at } 72^{\circ} \mathrm{C}\end{array}$ & Bhattacharjee et al., 2007 \\
\hline
\end{tabular}

Table 3: Isolation rate of $E$. coli and Klebsiella spp. from apparently healthy and clinical samples of cattle.

\begin{tabular}{|c|c|c|c|c|c|c|c|}
\hline \multirow{2}{*}{$\begin{array}{l}\text { Samples } \\
\text { (Source } \\
\text { /Origin) }\end{array}$} & & \multicolumn{3}{|c|}{$\begin{array}{c}\text { Presumptive positive isolates } \\
\text { (Biochemical tests) }\end{array}$} & \multicolumn{3}{|c|}{$\begin{array}{c}\text { Confirmed positive isolates } \\
\text { (PCR analysis) }\end{array}$} \\
\hline & & E. coli & Klebsiella spp. & Total & E. coli & Klebsiella spp. & Total \\
\hline & $\begin{array}{l}\text { Normal milk } \\
\quad(n=80)\end{array}$ & $16(20.0 \%)$ & $8(10.0 \%)$ & $24(30.0 \%)$ & $12(15.0 \%)$ & $5(6.25 \%)$ & $17(21.25 \%)$ \\
\hline & $\begin{array}{l}\text { Mastitic milk } \\
\quad(n=40)\end{array}$ & $24(60.0 \%)$ & $6(15.0 \%)$ & $30(75.0 \%)$ & $18(45.0 \%)$ & $4(10.0 \%)$ & $22(55.0 \%)$ \\
\hline \multirow[t]{2}{*}{ Cattle } & $\begin{array}{l}\text { Normal faecal } \\
\quad(n=80)\end{array}$ & 77 (96.25\%) & 7 (8.75\%) & $84(105.0 \%)$ & 72 (90.0\%) & $5(6.25 \%)$ & 77 (96.25\%) \\
\hline & $\begin{array}{l}\text { Diarrhoeic faecal } \\
\qquad(\mathrm{n}=40)\end{array}$ & $35(87.5 \%)$ & $3(7.5 \%)$ & 38 (95.0\%) & $33(82.5 \%)$ & $2(5.0 \%)$ & $35(87.5 \%)$ \\
\hline Total & 240 & $152(63.33 \%)$ & $24(10.0 \%)$ & 176 (73.33\%) & 135 (56.25\%) & $16(6.67 \%)$ & $151(62.91 \%)$ \\
\hline
\end{tabular}

Table 4: In vitro antimicrobial drug resistance pattern of E. coli and Klebsiella spp. Isolates.

\begin{tabular}{lccc}
\hline Antimicrobial agents & E. coli $(\mathrm{n}=135)$ & Klebsiella spp. $(\mathrm{n}=16)$ & Total $(151)$ \\
\cline { 2 - 4 } Conc. $(\mu \mathrm{g} / \mathrm{disc})$ & Resistance & Resistance & Resistance \\
\hline Imepenem (10) & $12(8.89 \%)$ & $3(18.75 \%)$ & $9.9 \%$ \\
Meropenem (10) & $5(3.7 \%)$ & $2(12.50 \%)$ & $4.6 \%$ \\
Cefotaxime (10) & $95(70.37 \%)$ & $14(87.5 \%)$ & $72.18 \%$ \\
Cefpodoxime (10) & $97(71.85 \%)$ & $11(68.75 \%)$ & $71.52 \%$ \\
Ceftazidime (30) & $73(54.07 \%)$ & $9(56.25 \%)$ & $54.30 \%$ \\
Ceftriazone (30) & $90(66.7 \%)$ & $11(68.75 \%)$ & $66.9 \%$ \\
Aztreonam (30) & $54(40.0 \%)$ & $7(43.75 \%)$ & $61.0 \%$ \\
Cefoxitin (30) & $14(10.37 \%)$ & $5(31.25 \%)$ & $12.58 \%$ \\
Ampicillin (25) & $120(88.88 \%)$ & $15(93.75 \%)$ & $89.40 \%$ \\
Gentamicin (10) & $0(0.0 \%)$ & $0(0.0 \%)$ & $0.0 \%$ \\
Amikacine (30) & $0(0.0 \%)$ & $0(0.0 \%)$ & $0.0 \%$ \\
Enrofloxacin (10) & $17(12.59 \%)$ & $1(12.5 \%)$ & $11.92 \%$ \\
Chloramphenicol $(30)$ & $0(0.0 \%)$ & $1(16.66 \%)$ & $0.7 \%$ \\
\hline
\end{tabular}


for $24 \mathrm{hrs}$. The result was interpreted as per CLSI guidelines (2019) (Fig 4).

\section{Detection of ESBL genes by polymerase chain reaction}

\section{Extraction of plasmid DNA}

Single pure colony of ESBL positive isolates were inoculated into $10 \mathrm{ml}$ of Luria-Bertani (LB) broth medium (HiMedia, India) and incubated at $37^{\circ} \mathrm{C}$ for $18 \mathrm{hrs}$ in shaking incubator. After that plasmid DNA was isolated using GeneJet plasmid
Miniprep kit (Thermo Scientific) as per the instruction of the manufacturers.

Detection of CTX-M genes (bla- ${ }_{\mathrm{CTX-M-1}}$, bla- ${ }_{\text {СтХ-M-9 }}$ ), blaand bla- ${ }_{\text {SHV }}$ genes

Genotypic confirmation of ESBL genes was done in a total reaction volume of $25 \mu \mathrm{l}$ for CTX-M and bla- ${ }_{\text {TEM }}$ as per method described by Dallenne et al. (2010) and bla- ${ }_{\text {SHV }}$ genes by Bhattacharjee et al. (2007). Amplicon size, primer sequence

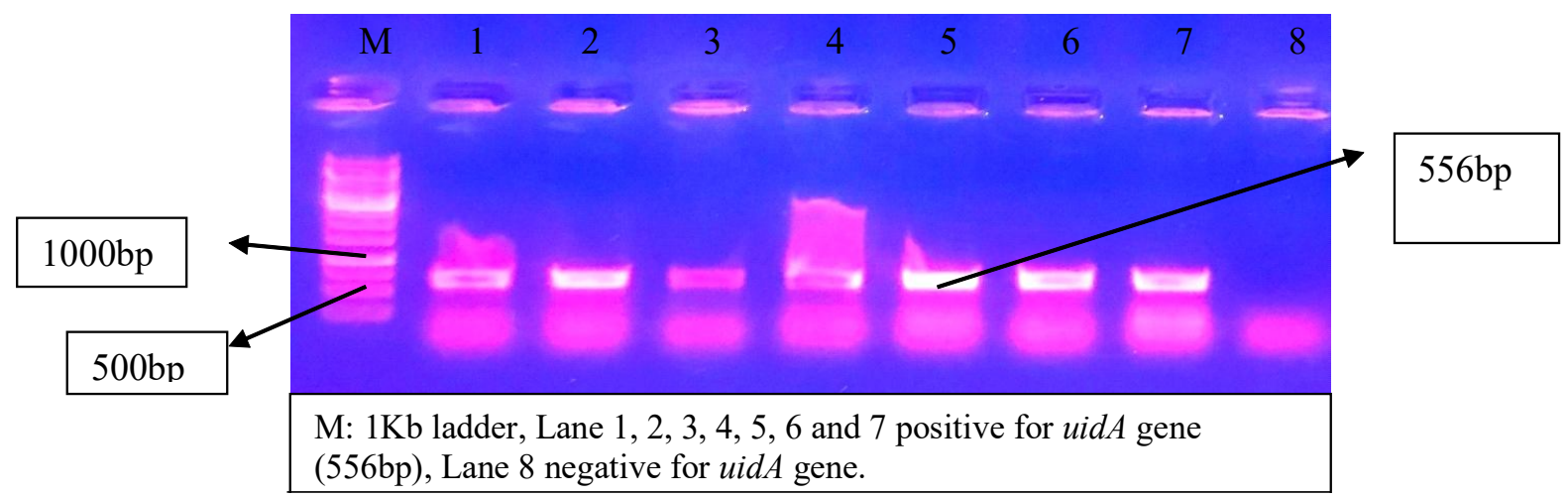

Fig 1: PCR amplification of uidA gene (556bp).

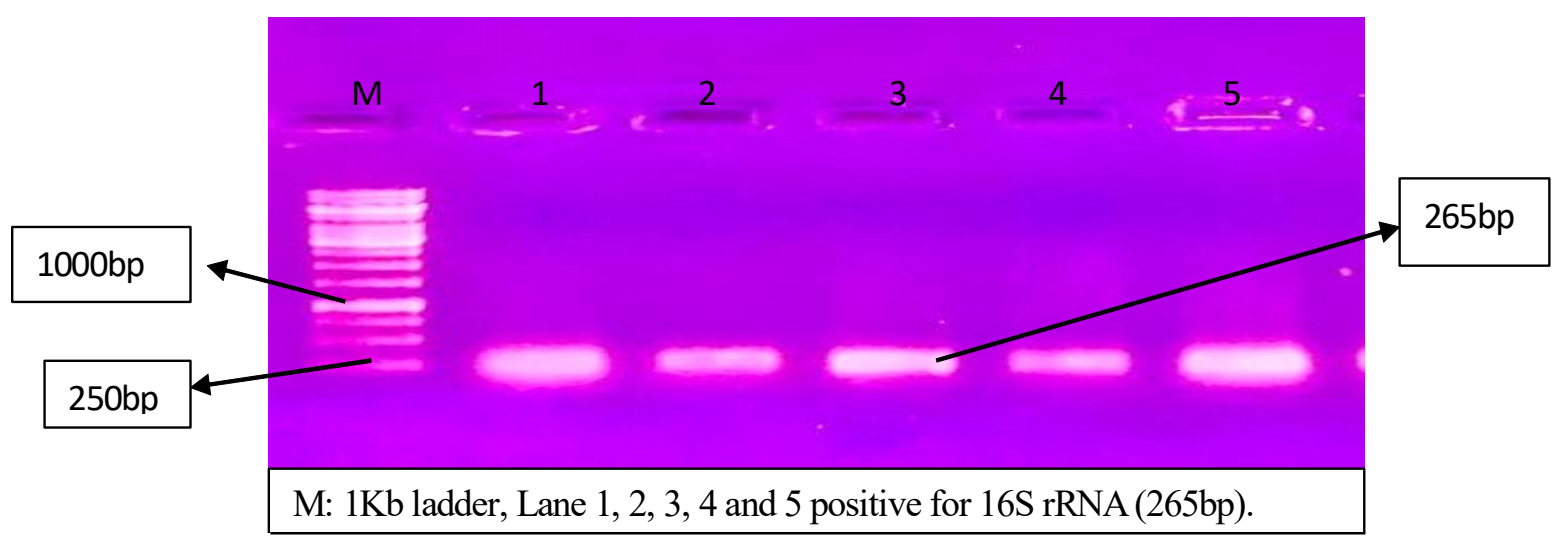

Fig 2: PCR amplification of $16 \mathrm{~S}$ rRNA gene (265bp).

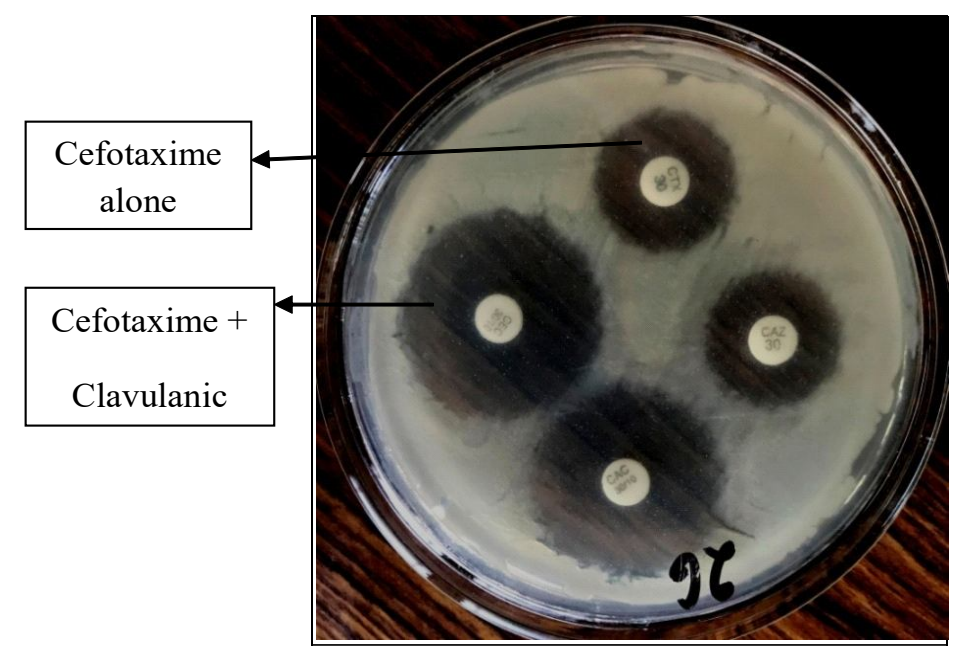

Fig 3: DDST for confirmation of ESBL producing E. coli and Klebsiella spp. 
of targeted genes and cyclic conditions of PCR are mentioned in Table 2. Multiplex PCR was performed for CTX$\mathrm{M}$ genes and simplex PCR was performed for bla- ${ }_{\text {TEM }}$ and bla- ${ }_{\text {SHV }}$ genes. Amplified products $(5 \mu \mathrm{l})$ were mixed with $3 \mu \mathrm{l}$ of bromophenol blue dye (6X) and electrophoresis was done in $2 \%$ agarose gel for CTX-M genes using $50 \mathrm{bp}$ ladder and in $0.8 \%$ gel for bla- ${ }_{\text {TEM }}$ and bla- ${ }_{\text {SHV }}$ genes using $1 \mathrm{~kb}$ ladder at 60-70 $\mathrm{mA}$ for $40 \mathrm{~min}$ and gel was visualized using the UV illuminator (GeNei Bangalore, India).

\section{RESULTS AND DISCUSSION}

A total 240 samples of milk and faeces were collected, out of which $152(63.33 \%)$ isolates were presumptively identified as E. coli and $24(10.0 \%)$ as Klebsiella spp. on the basis of morphological and biochemical characteristics. Further PCR analysis of these isolates confirmed 135 (56.25\%) as $E$. coli and $16(6.67 \%)$ as Klebsiella spp. (Table 3, Fig 1 and 2). In the present study, E. coli was predominant among isolates

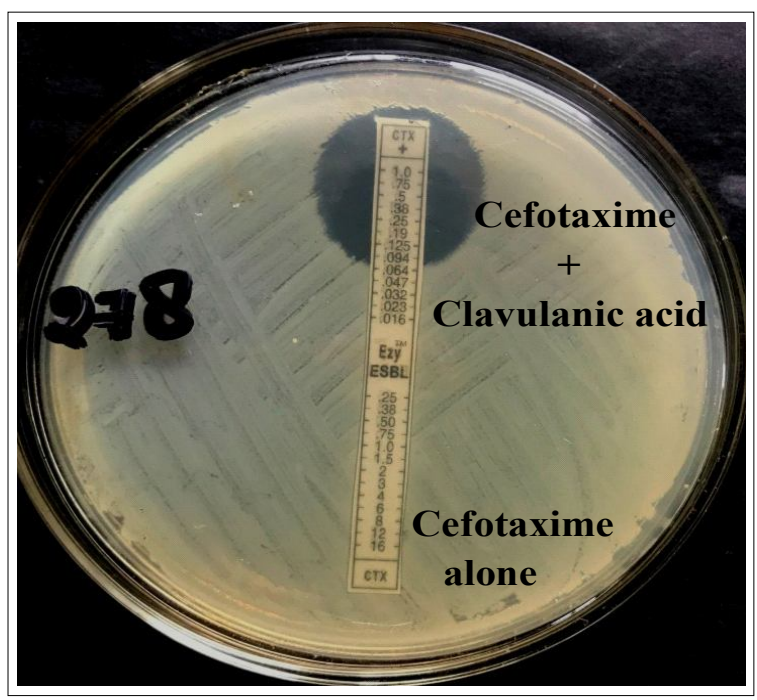

Fig 4: ESBL E-strip test for confirmation of ESBL producing E. coli. and Klebsiella spp.

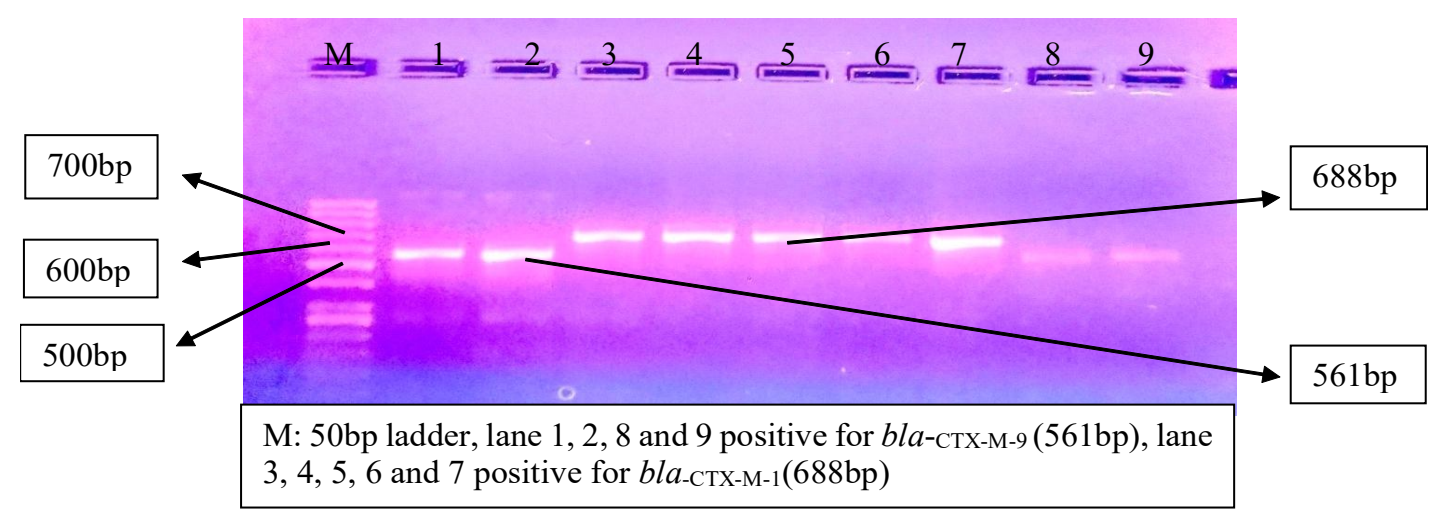

Fig 5: Multiplex PCR amplification of bla ${ }_{-\mathrm{CTX}-\mathrm{M}-1}(688 \mathrm{bp})$, and bla- ${ }_{\text {СтX-M-9 }}(561 \mathrm{bp})$.

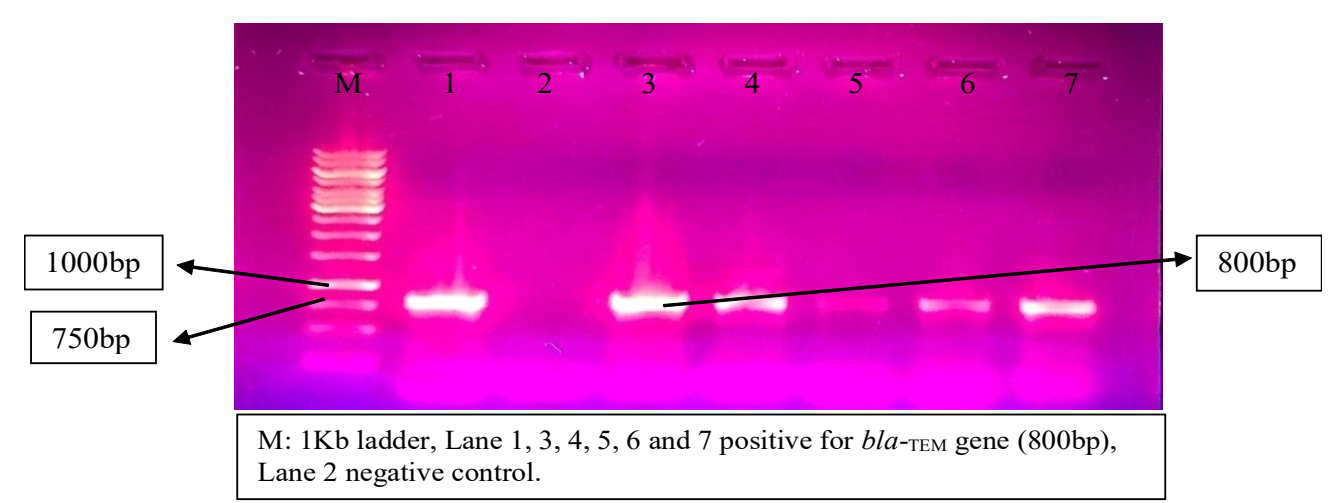

Fig 6: PCR amplification of bla- ${ }_{\text {TEM }}$ gene (800bp).

Table 5: Distribution of ESBL positive E. coli and Klebsiella spp. isolates according to screening, phenotypic and genotypic confirmation tests.

\begin{tabular}{lccr}
\hline \multirow{2}{*}{ Tests } & \multicolumn{3}{c}{ Positive ESBL } \\
\cline { 2 - 4 } & E. coli $(135)$ & Klebsiella spp.(16) & Total $(151)$ \\
\hline Screening test (AST) & $115 / 135=85.18 \%$ & $14 / 16=87.5 \%$ & $129 / 151=85.43 \%$ \\
Double disc synergy test (DDST) & $93 / 135=68.88 \%$ & $08 / 16=50.0 \%$ & $101 / 151=66.88 \%$ \\
ESBL-E test & $86 / 135=63.70$ & $06 / 16=37.5 \%$ & $92 / 151=60.92 \%$ \\
PCR & $82 / 135=60.74 \%$ & $05 / 16=31.25 \%$ & $87 / 151=57.61 \%$ \\
\hline
\end{tabular}




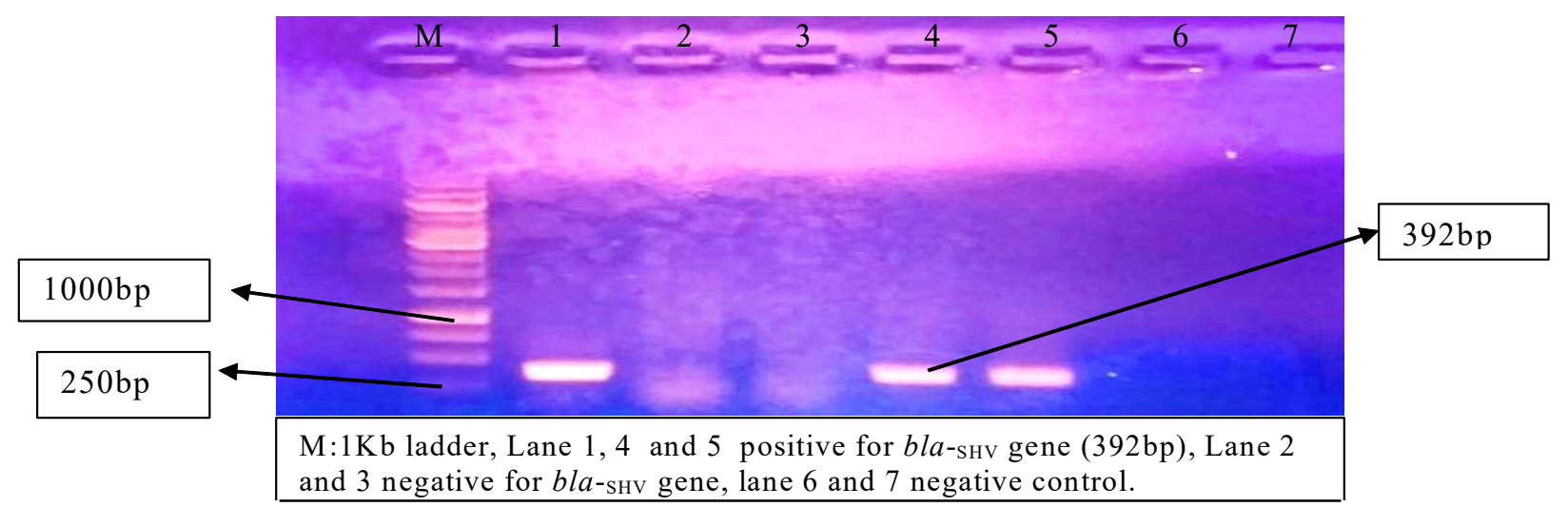

Fig 7: PCR amplification of bla- ${ }_{\text {HHV }}$ gene (392bp).

Table 6: Distribution of ESBL genes among ESBL positive isolates.

\begin{tabular}{|c|c|c|c|}
\hline \multirow{2}{*}{ No. of genes } & \multirow{2}{*}{ Bla-genes } & \multicolumn{2}{|c|}{ Positive isolates $(n=92)$} \\
\hline & & Number & Per cent \\
\hline \multirow[t]{4}{*}{ Single gene } & bla- $_{\text {CTX-M-1 }}$ & 60 & $65.21 \%$ \\
\hline & bla- ${ }_{\text {CTX-M-9 }}$ & 38 & $41.30 \%$ \\
\hline & bla- $_{\text {TEM }}$ & 29 & $31.52 \%$ \\
\hline & bla- ${ }_{\mathrm{SHV}}$ & 25 & $27.17 \%$ \\
\hline \multirow[t]{7}{*}{ Multiple genes } & bla- ${ }_{\text {CTX-M-1 }}$, bla- ${ }_{\text {СтX-M-9 }}$ & 7 & $7.60 \%$ \\
\hline & bla- ${ }_{\mathrm{CTX}-\mathrm{M}-\mathrm{g}}$ bla ${ }_{-\mathrm{SHV}}$ & 05 & $5.43 \%$ \\
\hline & bla- ${ }_{\mathrm{CTX}-\mathrm{M}-1,}$, bla- & 18 & $19.57 \%$ \\
\hline & bla- ${ }_{\mathrm{CTX}-\mathrm{M}-1}, b l a_{-\mathrm{SHV}}$ & 08 & $8.7 \%$ \\
\hline & bla- ${ }_{\text {СтX-м-9, }}$ bla- ${ }_{\mathrm{TEM}}$ & 03 & $3.26 \%$ \\
\hline & bla- ${ }_{\mathrm{CTX}-\mathrm{M}-1}$, bla- ${ }_{\mathrm{CTX}-\mathrm{M}-9}$, bla- ${ }_{\mathrm{SHV}}$ & 06 & $6.52 \%$ \\
\hline & bla- ${ }_{\text {СтХ-м-1 }}$, bla- ${ }_{\text {Стх-м-9, }}$ bla- ${ }_{\text {тЕм }}$ & 08 & $8.7 \%$ \\
\hline
\end{tabular}

recovered from both milk and faecal samples. These finding were in concordance with the findings of lbrahim et al. (2018) and Kotsoana et al. (2019). Higher isolation rate of $E$. coli in this study might be attributed to high prevalence of $E$. coli in the gut flora of ruminants.

The results of in vitro antimicrobial susceptibility test (AST) are mentioned in Table 4. The AST revealed that most resistant antibiotics were ampicillin $(89.40 \%)$ followed by cefotaxime $(72.18 \%)$, cefpodoxime $(71.52 \%)$, ceftriaxone (66.9\%), aztreonam (61.0\%) and ceftazidime (54.30\%) but drugs such as gentamicin, amikacin and chloramphenicol were found to be $100 \%$ sensitive. There are several reports that corroborate with the finding of this study (Ramasamy et al., 2021; Batabyal et al., 2018; Badri et al. 2017). In this study, carbapenem antibiotics like imipenem and meropenem also showed resistance against these isolates, $18.75 \%$ to $12.50 \%$ for Klebsiella spp. and 8.89 to $3.7 \%$ for E. coli respectively (Table 4). Although these antibiotics are not allowed to use in animal husbandry practices anywhere in the country, even then resistance in animal isolates may emerged and propagated as a result of clinical use in human medicine and transfer of these resistant genes to zoonotic pathogens (Bhardwaj, 2015). In this study $81.52 \%$ (75/92) isolates were found to be multidrug resistant (MDR), which highlighted a potential threat to human health and thereby limiting the therapeutic options.

The present study also aimed to determine the proportion of ESBL phenotypes among clinical and apparently healthy samples. Total 151 isolates (135 E. coli and 16 Klebsiella spp.) were subjected to screening and confirmatory phenotypic tests. Out of 151 isolates, 129 $(85.43 \%)$ were presumed as ESBL producer by AST. In phenotypic confirmatory testing, $101(66.88 \%)$ isolates were confirmed as ESBL positive by DDST and $92(60.92 \%$ by ESBL-E strip test. Final confirmation was done by PCR analysis which revealed $87(57.61 \%)$ ESBL positive isolates (Table 5). There was little difference in the sensitivity of both phenotypic confirmatory tests and PCR analysis and this observation corroborated with the findings of Badri et al. (2017) and Olowe et al. (2015).

Gene distribution study of ESBL positive isolates was carried out using PCR by targeting CTX-M (bla- ${ }_{\text {CTX-M-1 }}$, blaстХ-м-9), bla- ${ }_{\text {TEM }}$ and bla- ${ }_{\text {SHV }}$ genes (Fig 5, 6, 7). Over all prevalence of ESBL gene was found to be $65.21 \%$ for blaСTX-м-1 followed by bla- ${ }_{\text {CTX-M-9, }}$, bla- ${ }_{\text {TEM }}$ and bla- ${ }_{\text {SHV }}$ with $41.30 \%$, $31.52 \%$ and $27.17 \%$, respectively. The present finding revealed predominance of bla- ${ }_{\text {СтX-M- }}$ gene in this area. Similarly various co-workers across the world have also 
reported high frequency of bla- ${ }_{\text {CTX-M }}$ gene in different sample sources (Badri et al., 2017; Ibrahim et al., 2018; Paghdar et al., 2020; Olowe et al., 2015; Yadav et al., 2019; Schmid et al., 2013). Multiple co-existences of bla genes were also observed which has been mentioned in Table 6. Similar to this finding, co-existence of bla genes was also reported by various workers (Yadav et al., 2019; Tekinar and Ozpinar 2016).

\section{CONCLUSION}

This study highlighted, higher occurrence of ESBL producing E. coli than Klebsiella spp. and most of the isolates showed resistance to ampicillin, $3^{\text {rd }}$ and $4^{\text {th }}$ generation cephalosporins, which is an alarming situation for this area. Despite this, some isolates of E. coli and Klebsiella spp. also exhibited resistance against carbapenems, even without its use in animal husbandry practices, which are not a good sign from public health point of view. Therefore, a specific study on rational use of antibiotics and continuous monitoring for resistance genes against these antibiotics in livestock is warranted.

\section{ACKNOWLEDGEMENT}

The author is thankful to Dean, College of Veterinary Sciences and Animal Husbandry, Kumarganj and livestock owners of the Ayodhya and Sultanpur districts for their kind support during collection of samples.

\section{Conflict of interest: None.}

\section{REFERENCES}

Anbazhagan, D., Kathirvalu, G.G., Mansor, M., Yan, G.O.S., Yusof, M.Y. and Sckaran, S.D. (2010). Multiplex PCR assays for the detection of Enterobacteriaeceae in clinical samples. African Journal of Microbiology Research. 4(11): 1186-1191.

Andersson, A.F., Lindberg, M., Jakobsson, H., Backhed, F., Nyren, P. and Engstrand, L. (2008). Comparative analysis of human gut microbiota by barcoded pyrosequencing. PLoS One.

Badri, A.M., Ibrahim, T.I., Mohamed, S.G., Garbi, M.I., Kabbashi, A.S. and Arbab M.H. (2017). Prevalence of ESBL producing $E$. coli and $K$. pneumoniae isolated from raw milk samples in Al Jazirah State, Sudan. Molecular Biology. 7(1): DOI:10.4172/2168-9547.1000201.

Batabyal, K., Banerjee, A., Pal, S., Dey, S., Joardar, S.N., Samanta, I., Isore, D.P. and Singh, A.D. (2018). Detection, characterization and antibiogram of ESBL $E$. coli isolated from bovine milk samples in West Bengal, India. Veterinary World. 11(10): 1423-1427.

Bauer, A. W., Kirby, W. M., Sherris, J. S. and Turck, M. (1966). Antibiotic susceptibility testing by standardized single disc method. American Journal of Clinical Pathology. 45: 493.

Bhardwaj, M., Singh, B.R., Murugan, M.S. and Prasannavadhana, D.S. (2015). Emergence of Carbapenemase producing pathogens in animals. Pharmaceutica Analytica Acta. 6: 6, DOI:10.4172/2153-2435.1000379.
Bhattacharjee, A., Rajan Sen, M., Prakash, P. and Anupurba, S. (2007). Role of $\beta$-lactamase inhibitors in enterobacterial isolates producing ESBLs. Journal of Antimicrobial Chemotherapy. 61: 309-314.

Clinical and Laboratory Standards Institute (2019). Performance standards for antimicrobial susceptibility testing. TwentyNinth Informational Supplement. CLSI document M100S29. Wayne, PA: Clinical and Laboratory Standards Institute.

Dallenne, C., Costa, D. A., Decre, D., Favier, C. and Arlet, G. (2010). Development of a set of multiplex PCR assays for the detection of genes encoding important $\beta$-lactamases in Enterobacteriaceae. Journal of Antimicrobial Chemotherapy. 65(3): 490-495.

Edward, P.R. and Ewing, W.H. (1972). Identification of Enterobacteriaceae ( $3^{\text {rd }}$ edn.). Burges publicity Co. Minneapolis, Minnesota. 55: 415.

Franco, S., Murphy, M.M., Li, G., Borjeson, T., Boboila, C. and Alt, F.W. (2008). DNA-PKcs and joining phase of Immunoglobulin heavy chain class switch recombination. Journal of Experimental Medicine. 205: 557-564.

Ibrahim, E.I., Sayed, F.H., Ashraf, M., Abd, E.I., Wahab, S.A.K. and Helmy A.T. (2018). Prevalence of ESBL producing Enterobacteriaceae isolated from bovine mastitis milk. Alexandria Journal of Veterinary Sciences. 58(1): 102-108.

Khachatryan, A.R., Hancock, D.D., Besser, T.E., Douglas, R. and Call, D.R. (2004). Role of calf-adapted E. coli in maintenance of antimicrobial drug resistance in dairy calves. Applied Environmental Microbiology. 70: 27522757.

Kotsoana, P., Montso, S.B.D., Ajay, K. and Collins, N.A. (2019). Antimicrobial resistance factors of ESBL producing $E$. coli and $K$. pneumoniae isolated from cattle farms and raw beef in North-west province, South Africa. Bio Med Research Internationals. 13 pages, http://doi.org/10.1155/ 1019/4318306.

Madec, J.Y., Haenni, M., Nordmann, P., Poirel, L. (2017). ESBL/ AmpC and carbapenemase producing Entero bacteriaceae in animals: a threat for humans. Clinical Microbiology Infections. 23(11): 826-833.

Olowe, O.A., Adewumi, O., Odewale, G., Ojurongbe, O. and Adefioye, O.J. (2015). Phenotypic and molecular characterization of ESBL producing $E$. coli obtained from animal faecal samples in Ado Ekiti, Nigeria. Journal of Environmental and Public health. http://dx.doi.org/ 10.1155/2015/497980.

Paghdar, D., Nayak, J., Mathakiya, R.A., Parmar, B.C., Gida, H.K. and Bhavsar, P.P. (2020). Isolation and Molecular characterization of ESBL producing $E$. coli from milk. Journal of Animal Research. 10(1): PP 143-148.

Ramasamy, T., Keerthana, S., Srinivasan, M.R., Chandrasekar, D., Porteen, K., Borthakur, A., Elamaran, A. and Sriram, P. (2021). Molecular characterization of antibiotic resistance gene pattern of $S$. aureus and $E$. coli in mastitis affected dairy cows. Indian Journal of Animal Research. 55(4): 463-468. 
Detection and Molecular Characterization of Extended-spectrum $\beta$-lactamase Producing E. coli and Klebsiella spp. Isolates...

Reuland, E.A., Overdevest, I.T., Al Naiemi, N., Kalpoe, J.S., Rijnsburger, M.C., Raadsen, S.A., Ligtenberg-Burgman, I., vanderZwaluw, K.W., Heck, M., Savelkoul, P. H., et al. (2013). High prevalence of ESBL-E carriage in Dutch community patients with gastrointestinal complaints. Clinical Microbiology and Infection. 19(6): 542-549.

Saravanan, M., Ramachandran, B. and Barabadi, H. (2018). The prevalence and drug resistance pattern of ESBLs producing Enterobacteriaceae in Africa. Microbial Pathogenesis. 114: 180-192.

Schmid, A., Hormansdorfer, S., Messelhausser, U., Kasbohrer, A., Sauter-Louis, C. Mansfeld, R. (2013). Prevalence of ESBL-producing E. coli on Bavarian Dairy and Beef Cattle Farms. Applied and Environmental Microbiology. 30273032.
Tekinar, I.H. and Ozpinar, H. (2016). Occurrence and characteristics of ESBLs producing Enterobacteriaceae from food of animal origin. Brazilian Journal of Microbiology. 47: 444451.

World Health Organization (2013). Critically important antimicrobials for human medicine- $3^{\text {rd }}$ revision [online]. Geneva Switzerland: (9789241504485).

Yadav, A., Joshi, N. and Joshi, R.K. (2019). Occurrence of ESBLs producing Enterobacteria in animal products and their Environments. International Journal of Current Microbiology and Applied Sciences. 8(5): 2255-2264. 